\title{
Research Agenda for the Built Environment in Latin America*
}

\begin{tabular}{|c|c|c|c|}
\hline \multicolumn{4}{|c|}{ Received: March 5, 2015 Accepted: September 14, 2015 Available on line: October 30, 2015} \\
\hline \multicolumn{4}{|c|}{ Claudia Beatriz Murray } \\
\hline \multicolumn{2}{|c|}{ PhD Geography/Architecture } & \multicolumn{2}{|c|}{ Research Fellow School of Real Estate \& Planning } \\
\hline \multicolumn{3}{|c|}{ University of Reading } & c.b.murray@reading.ac.uk \\
\hline \multicolumn{4}{|c|}{ Alex Abiko } \\
\hline Professor & \multicolumn{3}{|c|}{ Fullime Professor of the Polytechnic School } \\
\hline \multicolumn{3}{|c|}{ University of São Paulo } & alex.abiko@poli.usp.br \\
\hline \multicolumn{4}{|c|}{ Eliane Monetti } \\
\hline Dr. Eng. & \multicolumn{3}{|c|}{ Lecturer Polytechnic School } \\
\hline \multicolumn{3}{|c|}{ University of São Paulo } & eliane.monetti@usp.br \\
\hline
\end{tabular}

\section{Javier Peinado Ponton \\ M.Phil. (Housing). $\quad$ Associate professor School of Architecture \\ Pontificia Universidad Javeriana}

jpeinado@javeriana.edu.co

Abstract This paper disseminates the outcomes of a series of interdisciplinary and multi-sector research seminars that focused on current development problems in a region of fast urban growth. Qualitative data was collected during round table discussions and workshops involving practitioners and government officials from some of the largest economies in Latin America. The authors then grouped these discussions into coherent themes and framed them into current scholarly debates. After assessing the suitability of theory to respond to practice, the paper concludes with four key areas for further research, with the final aim to encourage more scholarly analysis that can better inform development policy in emerging economies.

Keywords community development; housing; land use; social participation; sustainable development; urban planning 


\section{Agenda de investigación para el urbanismo en América Latina}

Resumen Este artículo divulga los resultados de una serie de seminarios interdisciplinares y multisectoriales de investigación que se enfocaron en los problemas actuales de una región en rápido crecimiento urbano. Se recogió información cualitativa sobre varias de las mayores economías de América Latina, se hicieron mesas redondas y talleres que incluían profesionales en ejercicio y funcionarios estatales. Los autores agruparon estas discusiones por temas y los enmarcaron en debates académicos contemporáneos. Tras estimar la aptitud de la teoría para responder en la práctica, el artículo concluye planteando cuatro áreas clave para seguir investigando, con el propósito final de incrementar el análisis académico capaz de informar mejor sobre las políticas de desarrollo de las economías emergentes.

Palabras clave

desarrollo sostenible; vivienda; planificación urbana; uso de la tierra;

desarrollo comunitario; participación social

\section{Agenda de pesquisa para 0 urbanismo na América Latina}

Resumo Este artigo trás os resultados de uma série de seminários de pesquisa interdisciplinares e multisetoriais que contemplaram os atuais problemas de desenvolvimento em uma regiáo de rápido crescimento urbano. Foram coletados dados qualitativos ao longo das discussóes em mesas redondas e em oficinas de trabalho em que participaram técnicos, gestores e dirigentes públicos de algumas das maiores economias da América Latina. Os autores deste artigo agruparam as discussóes que ocorreram em temas coerentes e as enquadraram nos debates acadêmicos atuais. Após avaliar a adequação da teoria em responder às questóes dos problemas práticos, o artigo propóe quatro áreas-chave para as futuras pesquisas, com o objetivo final de encorajar mais análises acadêmicas que possam subsidiar as políticas de desenvolvimento nas economias emergentes.

Palavras chave desenvolvimento comunitário; habitação; uso do solo; participação; desenvolvimento sustentável; planejamento urbano 


\section{Introduction}

During September 2013 and April 2014, academics and government officials from Argentina, Brazil, Colombia, Panama, Venezuela and the UK participated in a series of interdisciplinary research seminars organized jointly by the School of Real Estate \& Planning, Henley Business School, University of Reading (UK); the Escola Politécnica University of São Paulo (Brazil), and the Architectural School at the Pontificia Universidad Javeriana (Colombia) (see Table 1 for list of events and Appendix 1 for list of participants by sector). Participants also included relevant industry representatives and postgraduate students from Latin American universities. The seminar series were part of a programme implemented by the authors to tackle development issues in Latin America. Topics covered included urban planning, design quality, sustainable construction, housing, real estate valuations and financial mechanisms for urban development.

Each day included a mix of presentations, workshops, question and answer (Q\&A) sessions and round table discussions. Prior to the seminars, a contextual introduction to the built environment issues in Latin America and the UK was offered to all participants as reading material. In addition provocation papers were written by UK academics and practitioners. These provocation papers were distributed to all attendees a week prior to the event to encourage reflections and propositions from Latin American participants.
All seminars were recorded and transcribed. In addition participants were encouraged to provide feedback during and after the seminars and provide topics for research in areas that they deemed in most need of scholarly analysis.

With the aim of developing a research agenda directly informed by practitioners and government representatives, this paper groups all qualitative data collected before, during and after the seminar series according to the different themes. These themes were later framed with relevant academic debates and theories in order to evaluate linkages, discrepancies or voids between theory and practice.

The paper is organized in three parts. First, there is a background section with the contextual arguments that were put forward for discussion during the seminars. Second, a section containing the analysis of participants' responses grouped according to the core themes of the seminars and framed around current theories that have been published in either English, Portuguese or Spanish. Third, after evaluating the suitability and responsiveness of theories to solve the urban issues presented by the different sectors, the paper concludes with the proposal of a new research agenda. All comments by seminar participants must remain anonymous, but in order to contextualize the arguments, an indication of the background and nationality of the contributors has been provided. 


\begin{tabular}{|c|c|c|c|}
\hline Event Name & Location & Date & Organising Partners \\
\hline $\begin{array}{l}\text { Developing social equality and economic } \\
\text { transparency for future cities. }\end{array}$ & Sao Paulo, Brazil & 23-26 September 2013 & $\begin{array}{l}\text { Brazil: University of Sao Paulo } \\
\text { Colombia: Universidad Pontificia Javeriana } \\
\text { UK: University of Reading, }\end{array}$ \\
\hline $\begin{array}{l}\text { Unleashing the potential of equality } \\
\text { and market transparency in urban } \\
\text { and rural Latin America. }\end{array}$ & Bogota, Colombia & 2-4 April 2014 & Colombia: Universidad Pontificia Javeriana. \\
\hline $\begin{array}{l}\text { World Urban Forum UN-Habitat: Mind } \\
\text { the gap: Linking theories of equitable } \\
\text { development with practice in Latin America }\end{array}$ & Medellin, Colombia & 8 April 2014 & $\begin{array}{c}\text { Brazil: University of Sao Paulo } \\
\text { Colombia: Universidad Pontificia Javeriana } \\
\text { UK: University of Reading, }\end{array}$ \\
\hline
\end{tabular}

\section{Background: bridging the UK- Latin America knowledge gap}

A report from the Government Equalities Office found that wealth inequality in the UK has increased since the 1980s (Hills et al., 2010) while a report by the Economic Commission for Latin America and the Caribbean (ECLAC) revealed that this region is the most unequal in the world (González \& Martner, 2012). Inequality materializes in the consumer society but is more evident when it affects human needs, such as food and shelter. In the UK, increased wealth and international migration have affected land prices, putting a strain in the affordability of housing (Nygaard, 2011). In Latin America, rural to urban migration and a housing deficit of 50 million units has also affected the market (UN-Habitat, 2011). The city is indeed triumphal for a few: while London is one of the world's playgrounds for the global elite (Glaeser, 2011), Mexico City is home to Carlos Slim, one of the richest men on Earth (Harvey, 2012). In comparing urban environments in the UK and Latin America there are obvious differences not only in geographical scale, volume of human traffic, and state of development, but also the intensity of the urban struggle: at the bottom of the pyramid the challenge for Latin Americans is often that of survival (Tironi, 2009) ${ }^{1}$.

Unlike the UK, social and economic issues in Latin America have long suffered from poor institutions and weak governments (Montaner, 2001). In addition, an inefficient tax collection system poses an insurmountable barrier for local governments to develop a welfare system (Bernardi, Barreix, Marenzi \& Profeta, 2007). According to the International Labour Organization (ILO) there are 127 million people working in the "informal" sector in Latin America. The ILO report states that some countries have made good progress to keep informality rates 
below $50 \%$ but low-income Andean and Central American countries still experience rates of $70 \%$ or more (International Labour Organization, 2014). Nearly $50 \%$ of the population in the region has no job security, no health coverage and pays little or no contribution to support the welfare system. In addition, colonial style clientelism and elitism means that most rich families manage to receive tax exemptions from government officials. This places the burden on the poorest sector of the population as value added tax is the main source of government income (Harvey, 2012). Policymakers, academics and experts are increasingly concerned over the widening gap between Latin American countries and developed economies such as the UK. Some claim that globalization is mostly to blame (Chomsky, 2010; Stiglitz, 2003) while others maintain that the problem of inequality is not related to recent changes in globalization but rooted in the region's own missed opportunities and wrong turnings in history (Fukuyama, 2008; Montaner, 2001). The main question for Fukuyama is why are other countries in East Asia (e. g. Taiwan, South Korea) closing the gap with the developed world and Latin America cannot? Responding to this question, Fukuyama mentions, among other factors, the neglect of economic inequality that so far many governments in the region have shown, and lack of property rights.

Peruvian economist Hernando de Soto also argues that lack of property rights affects Latin America's poor as they are unable to use their property as collateral and become entrepreneurs (De Soto, 2001). His views have been challenged (Frankema, 2006; Gilbert, 2002; Samuelson, 2001) but followed and praised by politicians (Clift, 2003; Fernandes, 2002). Some argue the time for debate is over and what is needed is action to solve the problem, as a practitioner recently put it in an urban design workshop in Rio de Janeiro: "You cannot change the tyre while riding the bike" (quoted in Nicholson, 2013). In other words, while the theoretical argument unfolds, urban development in the region will keep expanding.

Such urban development is inevitable — cities produce $50 \%$ of countries' gross domestic products, which leads to increasing competition to attract development and real estate investment (Lall, 2013). Still, parallel growth in inequality suggests that this expansion is not benefiting all citizens (González and Martner, 2012; Lima, 2006; Murray, in press). Urban sprawl has been directly related to social fragmentation as well as to environmental disasters, and yet urban planning systems in Latin America have not responded to this combined problem (Bäbr \& Borsdorf, 2005; Romero \& Ordenes, 2004). Furthermore, there is a lack of interaction between planning, regional geographies, climates and cultural habits, which is directly affecting urban air quality (Romero, Ihl, Rivera, Zalazar \& Azocar, 1999). The main question is how to solve these problems? Are the methodologies used in the developed world transferable to areas of rapid urbanization? (De la Torre Fajnzylber \& Nash, 2009; Jenks \& Burgess, 2000). There are several who outline the difficulties in adapting advanced methods to the region. For example, social fragmentation is manifested not only in the development of gated neighbourhoods but also in the widespread use of private cars (Onursal \& Gautam, 1997). So how is it possible to curb carbon emissions and introduce sustainable transport without addressing this refusal to interact with others? Another matter is whether Latin America has the technology to develop greener urban environments; some claim this is not the case (Lankao, 2007). Furthermore, what financial mechanisms do emerging markets have to adopt strategies employed in the developed world? (Satterthwaite, Huq, Pelling, Reid \& Lankao, 2007). In this context, how can Latin American cities 
secure the provision of social housing with an inefficient tax collection system that has historically constrained the welfare system (Bernardi $e t$ al., 2007; Bird, 2003; Harvey, 2012; Montaner, 2001)? There are also critical questions regarding the implementation of sustainable planning systems and the lack of power of local authorities over certain elites (Brain \& Sabatini, 2006; Bulkeley \& Betsill, 2005; Thibert \& Osorio, 2014). Equally, in a divided society the politics of planning encounter daily confrontations from lower income sectors that see no benefit in strong neoliberal approaches that aim at attracting private and foreign investment (Burgess, Carmona \& Kolstee, 1997).

The seminar series held in São Paulo in September 2013, and Bogota and Medellin in April 2014, facilitated engagement between academics, government officials and practitioners, exploring existing theory-practice gaps around these issues. The summary of the discussions that follows are their direct answers to these questions.

\section{Summary of discussions according to the themes covered}

\section{Sustainability and the built environment}

When discussing the definition of sustainability, as understood by the different nationalities, the consensus during the seminars was that sustainability is a topic very usually approached from the developed North and that there is a need to think more about what happens in the Global South. A University of São Paulo (USP) professor pointed out that: "In Latin America we take approaches across the border and don't take into account particularities of location" stating that there's a need to measure energy consumption in tropical locations, for example. But climatic differences are not the only issues considered by academics when discussing and contrasting sustainability in the Global North and South. In a recent study that compares Long Island in $\mathrm{New}$ York (USA) with the remote island of Chiloe (Chile), scientists warn that education and cultural understanding of the world can also have an impact on people's view of sustainability (Vercoe \& Brinkmann, 2012).

The importance of context led to the question of climate change, and whether or not this is a big priority for Latin America. It was argued that this is a global priority, but there was a need for a more regional understanding and definition. Placing sustainability in the regional context and deconstructing goals into more manageable parts has long been recommended by academics (Dovers, 1995) and more recently framed within the global problem-local action debate (Gupta, Van der Leew \& De Moel, 2007; Parris \& Kates, 2003). The lack of contextualization of sustainable development in Latin America to feed into policies was denounced early in this century (Swinton, Escobar \& Reardon, 2003). The response to the growing concerns was the development by ECLAC of three pivotal documents, which in accordance with regional theories of sustainable growth look at reaching economic targets while simultaneously ensuring (a) equal share of prosperity among all sectors of society; (b) reducing carbon emissions; and (c) avoiding the depletion of natural resources (ECLAC, 2010; 2012; 2014).

Few practitioners at the seminars were aware of the work of Eclac — and indeed the gap between theory and practice became evident as some planning officers noted during the seminars that when policies for sustainable development become operational, they showed flaws precisely in terms of inequality and equal distribution of responsibilities, which relates to the work of ECLAC. It was revealed, for example, 
by a seminar participant from Brazil that in São Paulo the regulation to control car traffic in the city centre imposes time restrictions according to number plates during the rush hour. Most people comply with this measure, but wealthy individuals sometimes buy an extra car with a different number plate, so in reality the restriction does not affect them but falls heavily on the middle classes. This measure not only increased car use in São Paulo — as well as in Bogota where a similar system of "pico y placa" exists ${ }^{2}$ — but it is also widening the gap between the rich and the other sectors of society that cannot afford the luxury of a second car.

Relevant theories stress that if policies to reduce carbon emissions are going to have public acceptance, they must be fairly applied (Wilkinson $\&$ Pickett, 2009). These authors also argue that equality in the community can help to reduce carbon emissions by increasing the acceptance of policies and reducing the cost of policing. In this context, a Venezuelan representative put the issue of equality and sustainability at a global level. The question presented was how Latin American countries compare to other developed nations in terms of their carbon footprint? Shouldn't nations with higher levels of energy consumption contribute more than poorer nations with less consumption? According to this planning official, developing countries should be allowed a level of economic growth to guarantee the quality of life currently enjoyed by developed nations. The implication from these remarks is that reducing the carbon footprint will affect economic growth, which highlights another theory-practice gap. Cuba, a close neighbour of Venezuela, is the only country in the world that is managing high levels of growth with low energy consumption, perhaps an example not only of the viability of such an attempt but also a hint that reducing carbon emissions does not always imply slow economic growth ${ }^{3}$.

If sustainability requires equality and contextualization to suit Latin American conditions, the questions posed by a UK academic were as follows. What are the positive features that Latin American cities have that can be increased? What is the sustainable shape of its cities that can be built and invested in? In response, an attendee from a Colombian government organization, stated that there is little research on resilience in Colombia, and the way the government has to prioritize development activities is by responding to natural disasters. So if people are living in more vulnerable places (e. g. subject to torrential rains, land slides, etc.) the government directs more resources to those areas. Much of this short-termism is blamed on politics. So if long-term approaches are needed in order to combat climate change and build resilient cities, Latin America should depoliticize planning; furthermore, the Colombian view during the seminars was that an apolitical body acting as an advisor could be created, although the participant could not elaborate further on the format and responsibilities of such an organization.

\section{Planning and public services}

In part due to the heavy politicization of planning, spatial regulations in Latin America tend to be short term in comparison to the UK. Master planning continues to be a top-down approach with little public consultation. The consensus from all of the participating countries was that 
citizens' participation is needed so urban plans belong to the people and are not at the mercy of political change. The slogan "Planning for the next generation and not for the next election" was presented by a Colombian representative.

The biggest question was around land value capture (LVC) and equitable distribution of benefits ${ }^{4}$. A Colombian participant referred to a current masterplan at the periphery of Bogota where, even though still on the drawing board, news of its implementation was somehow leaked to a small sector of the population. As a result, land values in the area have spiralled up and there is now no available land within the masterplan for social housing as the costs are too high. "Governments can create bad incentives" - the Colombian participant stated_- "when change of [land] use happens we need to think how to benefit the wider population and not just one small sector". The academic literature confirms the claim that there are high profits to be made in expanding cities towards the periphery. Turning rural land into urban land, in Colombia at the turn of the last century, yielded profits of up to $550 \%$ of its original value (Chiape de Villa, 1999).

Lack of government control over the benefits of land value, adds an extra strain to the small amount of finance available for public services and infrastructure. Although in many Latin American cities transport is improving, this is seldom due to developers' contributions. It was pointed out by a Brazilian academic that only two countries, Brazil and Colombia, have started to implement LVC policies to benefit the public realm, a claim also made in the academic literature (Murray, in press; Smolka, 2012; 2013). Government official documents and academic literature highlight Law 388, 1997, as an important change for Colombia towards regulation of development contributions and securing land for social housing; and in the case of Brazil (and more specifically São Paulo) the so-called Special Social Interest Zones (Zonas Especiais de Interesse Social, ZEIS) are highlighted as important. The ZEIS is a new regulation that requires developers to include a certain percentage of social housing in all developments. However, some argued during the seminars that these regulations can be inefficient. In the case of Colombia, the capital city of Bogota does not fully comply with the Law 388, and has created its own legislation; furthermore, government officials working recently in remote cities in the Caribbean claimed that when quoting Law 388 to local planning authorities, the response was "That normative never arrived here" . As a result, the reality is that the majority of social housing in Colombia concentrates in small municipalities around major urban centres with low land values: "This creates a total imbalance as the populations do not have infrastructure and are not provided with health and educational support" claimed a government participant from that country.

In the case of São Paulo, it was stated that the ZEIS is providing good results, but more is needed to increase infrastructure. The cost of not having a good provision of public transport is affecting not only air quality but the quality of life of the millions of the city's inhabitants

This topic became so important during our discussions in São Paulo that the research team organized a workshop on LVC during the UN-Habitat meeting in Medellin (Colombia) in 2014.

5 The roots of such a statement can be found in colonial times. Spanish bureaucrats used to acknowledge receipt of a new law by placing the legislation on their heads and stating "Obedezco, pero no cumplo" ("I obey but I do not enforce"). Paradoxically this was accepted by the Crown and even if the rules were issued, enforcement was at the local officer's discretion. Some argue today that this has created a culture of inefficiency in many Latin American countries (Heras Gómez, 2004) 
that rely on their cars for mobility (Biderman, 2008). But if Brazil and Colombia are the most experienced, others are struggling. It has been reported that Argentina and Chile are lagging behind in implementing efficient LVC mechanisms and both countries rely heavily on fiscal land for social housing (Brain \& Sabatini, 2006; Murray, in press). In the case of Venezuela, even if the government is sympathetic to LVC mechanisms, their use is not widely implemented across the country (Smolka, 2012).

Upgrading favelas, by providing public services, was seen as a step in the right direction by many participants in several round table discussions. This was mainly because governments in Latin America are seeing the benefits of avoiding conflict, keeping residents close to their places of work and maintaining local networks (Abiko \& Coutanceau, 2013; Betancour, 2007; Boldarini, 2008). But there are conflicting arguments regarding the legalization of land titles and the success of these schemes in several countries has been challenged in the academic literature (Cuervo \& Jaramillo, 2009; Gilbert, 2002; Van Gelder, 2009). The main issue is that titling theory clashes with the realities of capitalism, because even if applicants succeed in legalizing their land titles they are still not creditworthy to the banks as many do not have a permanent job. Furthermore, some find it difficult to pay land taxes and services, risking again dispossession by local authorities.

Still, the common consensus from government and practitioners during the seminars was that upgrading plans are yielding good results. Many cited the success of the various cable cars schemes (e. g. in Medellin, Rio de Janeiro and La Paz) that connects the slums with the city centres. For this group, all the upgrading plans now need is further improvement. For example, the vast areas of land and housing that even a small favela covers need to be better connected to the rest of the city, in order to guarantee that their population remains economically active with easy access to jobs. To the argument that favelas were "well located anyway", it was pointed out that although the outskirts of the favelas are located near commercial centres, there are still many people trapped inside in the centres of the favelas, far from the edges where more connectivity to transport occurs (De França \& Abiko, 2013). Others contradicted the good location argument and stated that some favelas do not have the luxury of a good location - therefore long hours of commuting are becoming so common that the slogan used by the Brazilian government for their housing programme "My House, My Life" (Programa Minha Casa Minha Vida, PMCMV) is now becoming widely known in São Paulo as "My Bus, My Life".

Paradoxically, even if upgrading programmes were considered by some seminar participants as a good alternative to solving Latin America's housing deficit, the academic literature claims that, in practice, governments are sometimes reluctant to implement upgrading programmes and that the tendency is to prioritize development of new housing stock (Cuervo \& Jaramillo, 2009; Gilbert, 1997; Murillo, 2001; Murray, in press; Scheinshon \& Cabrera, 2009). These authors suggest that the problem lies in the reliance of large housing programmes to generate construction jobs in a region characterized by low-skill workers. Official government websites that currently promote large housing programmes in all countries participating in the seminars (Programa Crédito Argentino, Pro.Cre.Ar, in Argentina; PMCMV in Brazil; 100.000 Free Houses in Colombia; and Housing Venezuela) have, as an overall publicly declared objective, to boost productivity in the construction sector and support the national economy. 
Favela dwellers or not, the reality of the city as revealed by an academic from USP is that in Sáo Paulo, $50 \%$ of the population live in one area of the city, while $70 \%$ of jobs are located in another. It was stated that in Colombia the situation is also similar, but with the additional problem that local and national governments do not always work together; so to develop a coherent transport network within the city of Bogota is a problem that can aggravate at both the regional and national level. Furthermore, it seems that the planning system in some Latin American countries should take a more flexible approach:

We [in Colombia] have too many planning rules. Everything is regulated. So this creates a problem because local authorities sometimes sit quietly behind the rules and don't allow for change to happen. This is something that becomes obvious with land invasion, favelas, etc. People cannot wait for rules to change, so they just act, even settling in high-risk areas. This shows that we need more than rules if we want to control urban dynamics in Colombia (workshop participant).

The implication here is that a more discretionary planning system is needed, but the academic literature in Argentina indicates the opposite. In metropolitan Buenos Aires the planning process is lengthy and opaque, as planning delay usually pushes developers to break ground as soon as the land is purchased. This is done with the hope that planning permission will be "solved" at some stage at the local officer's discretion (De Duren, 2006; Thuillier, 2005).

\section{Housing}

There were several issues in dealing with housing and, in particular, with informal development. The following subsections describe group discussions held in São Paulo, in 2013 and in Bogota, in 2014 .

\section{Social and cultural}

The Brazilian government pointed out the fact that large housing programmes, such as the PMCMV, targeted a very specific group: very low income families living in favelas (slums). A government official stated:

Some of these families have always lived in informal set-
tlements. They are the fourth or fifth generation living
in favelas. So providing them with a new house is also
a cultural issue. One of those is to do with maintenance
- how to get them to look after their houses. So we
are not just delivering homes, there are also other fac-
tors like informing people on the economic and prac-
tical issues of keeping a house (workshop participant).

There has been some research carried out regarding quality and sustainability of social housing stock (Kowaltowski et al., 2006) which uses post-occupancy evaluation as a methdod to measure satisfaction; but the Brazilian government expressed their interest in more of such studies using post-occupational surveys to help them in the monitoring process of the units delivered thus far, and also to monitor the conditions that families are living in now. The Colombian government also expressed a need to monitor the outcomes of their housing projects: "We are rehousing extremely vulnerable sectors of our population that in our case often come into the cities pushed by violence" - referring to the FARC (Fuerzas Armadas Revolucionarias de Colombia) conflict- "or natural disasters". An example a Colombian participant gave for the need to understand cultural issues and to monitor customers' satisfaction illustrates the problem.

[In Colombia] there was an entire population that was relocated within the coastal city where they lived. They used to live in houses on stilts by the sea because they were a community of fishermen. Now [after relocation] they were moved to the city centre to live in concrete block houses, away from their livelihood (workshop participant). 
So even if government action was well intended, as the living conditions of the community were deemed unsafe, the example clearly shows that there was little understanding of the cultural needs and perhaps no community consultation prior to the relocation.

\section{Community building}

Brazilian, Colombian and Venezuelan authorities acknowledged that community building is one of their biggest challenges. How to rebuild the communities once the favelas have been upgraded? All have different methods, but while some agree that they are very archaic (e. g. Brazil), others recognize that they don't have a methodology and they are in a process of learning while doing (e. g. Venezuela). A Brazilian official stated:

I'm doing a bit of self-criticism here, these are programmes that we call movimento tecnico social, whereby people spend too long in classrooms doing courses. These people are young and mostly women, they don't even get proper support on issues related to domestic violence. The system is not working. I think we need to update these programmes for example with technologies - the mobile phone is something that we use very little and we could use it more as a way of spreading information (workshop participant).

The problem is aggravated when ex-favela dwellers receive their new flats in a building block. Although favela dwellers are used to living in close proximity, in the favela each one was the "owner" of his/her space and able to incrementally change their homes - a practice they also want to exercise in their new homes:

This is a big problem for us [in Brazil]. Local governments want to deliver houses expecting people to keep them as they are. But people want to add their own "touch" to the units, they want to make alterations. And that in a communal block is difficult so we need to think about that, about how the community can get more involved in the maintenance of their places.
International referents of how other places deal with this - we have many, but we still don't know how to transfer this to our country (workshop participant).

But some other countries, such as Venezuela, are much more comfortable with people taking the initiative. They are tapping into the high degree of social cohesion of their barrios (slums), and turning that into a powerful design tool. One planning officer said:

In the informal sector people have common and very basic needs and they know the only way to solve them is by getting together as a community [...]. In other sectors of the population where there's no such a need, we find that it is more difficult to get the community to take a more pro-active approach (workshop participant).

In Colombia it was revealed that, although public consultation is compulsory, there's no real engagement. The format they use (community meetings, presentations of new developments, etc.) are just a new addition to the bureaucracy of the system, but in reality community feedback is seldom taken into account. The shortcomings of community participation in the upgrading process of informal settlements has long been acknowledged by academics in the particular cases of Colombia and Venezuela (Gilbert \& Ward, 1984). These authors claim that tenure is important because owners tend to engage more in communal activities than tenants. Also projects intending to tackle vital needs (e. g. provision of water, electricity, etc.) had more support. These findings relate to other academic studies in participatory processes, which encourage policymakers to acknowledge and address the question of "What is in it for me?" that most participants ask themselves about community projects (Parker \& Murray, 2012).

But even if governments and academics agree that more studies are needed in terms of cultural 
changes to communities as consequence of housing programmes, there seems to be an immense wealth of data collected by non-governmental organizations (NGO), which is currently not widely used by either sector. One of the participants to the seminars in Bogota was a director of the Colombian programme "Cómo vamos" (CV). This organization started in 1998 and uses a bundle of indicators to monitor the effect of urban development on citizens and their quality of life. The organization later expanded to other Colombian cities and to the rest of Latin America. Another organization collecting data, which is equally overlooked, is Techo. This NGO began in 1997 in Chile as a youth organization to help families in extreme poverty. In recent years the Colombian bank for sustainable development (Findeter, Financiera de Desarollo Territorial) subcontracted $\mathrm{CV}$ in order to monitor their programmes, but the other countries do not seem to exploit the potential of such organizations. The reasons for this disconnection did not appear at all clear during the seminars, but what was clear were the consequences: there is duplication of effort as government, academics and NGO all attempt to carry out their own surveys and studies and, more worryingly, as the director of CV expressed, "There is a risk of exhausting communities, something we are already seeing in some villages, who these days tend to be less willing to participate in surveys".

\section{Housing quality}

This was presented as an issue of high importance for all the countries. It was acknowledged by the Brazilian government that at the beginning of the PMCMV, quality was overlooked and that they are now seeing the consequences of poor design and poor quality. This is acknowledged in the academic literature (De França \& Abiko, 2013; Formoso, Leite \& Miron, 2011; Kowaltowslki et al., 2006; Murray, 2013). Poor construction quality adds to the already mounting issues of buildings maintenance. $T$ said:

The problem that we have from these housing blocks is the payment for maintenance charges. Because we are addressing a section of the population that has no knowledge of community life [...] so we need to do a programme to promote that insertion and also to make sure that they don't deteriorate the quality of the buildings (workshop participant).

The issue of cost and quality of affordable housing was also acknowledged in Colombia, and in Argentina it was revealed that the best efforts in quality improvement of social housing tend to come from NGO or workers' co-operatives, who are finding new roles as social housing developers.

\section{House pricing}

What transpired from all participating countries is that most housing initiatives are creating a considerable cultural change on people's behaviour within their dwellings but also in their exposure to debt. This is embedded in all the subsidized housing systems that rely in the famous $\mathrm{ABC}$ rule (Ahorro, Bono, Crédito: savings, subsidy, credit). Through this system, a large group that had previously no knowledge of debt, are finding themselves with the responsibility of paying a mortgage. It was highlighted during the seminars by a UK academic that Latin American governments must implement plans to educate this vast section of the population, otherwise the risk of spreading another subprime mortgage crisis could be quite high. Most governments have no default mechanisms in place to deal with non-payment of mortgages. They rely on public funds and, as expressed during a round table discussion, the risk is that if the country's growth diminishes, then government guarantees will diminish. In answer to this the Brazilian government official 
pointed out the social cost of eviction or any other default mechanism:

Today this is one of my biggest questions, because these are vulnerable families, so how do you deal with mortgage payments with them? Do we use normal mechanisms? What are you going to do? Take them out of the houses because they are not paying? And put them where? What is the economic and social cost of this? (workshop participant).

The economic advisor to the PMCMV admitted that there is a complete lack of knowledge in terms of house prices. He stated:

In favelas we don't have information about the size of the houses, we don't even know the value of the land. We are advancing in themes related to construction but we have nothing in relation to property. That is one of the projects where we need more research (workshop participant).

Colombia also exposed their lack of information:

We have cadastral information in all cities but not on the three largest ones [...] in terms of property transactions we have two main problems, first that many transactions are in the informal market and therefore not reported, and second that the ones that are reported are usually undervalued so as not to pay full transaction costs to local authorities (workshop participant).

According to academic studies it is possible to collect informal land market information (Abramo, 2008). This author also highlights land transactions in the informal market as a high priority area for further research for Latin America

Lack of availability of data was a common problem not only for valuation of favela dwellings but also for monitoring the progress or failure of mass housing programmes. Colombia reported that they have a completely opaque market not only in regard to data of low-income housing groups, but also at higher levels as well. The claim by many participants was that the very little available data is mainly distorted or biased. Brazil also acknowledged a lack of reliable information even for large real estate valuations. The question raised by UK academics was if it were possible to collect data and, if so, where to start and data of what type? Many countries agreed they need advice on what is relevant and what is not when it comes to real estate databases, but it was highlighted that closer research interaction with the banking sector could be beneficial. The other, more pressing, question was what to do in a market that has no data but is attracting international investors? For some UK academics, the divergences in valuation techniques due to inefficient data collection were not relevant, what was important was to know how those valuations were impacting on the markets and in a wider sense Latin American society as a whole.

\section{Conclusions}

In this paper we considered data collected during and after the research seminars along with relevant academic literature. We can now identify four key areas in need of further research in order to aid regional policy.

\section{Equitable distribution of LVC}

What transpired throughout the knowledge-exchange seminars was that, in Latin American countries, there is little connection between planning and finance, and that LVC is not equitably distributed between all sectors of the population. This inefficiency is not only constraining the development of infrastructure and the provision of affordable housing, but is also breeding inequality and impoverishing the quality of the built environment. The main question here is what planning policies (if any) are in place to guarantee improvement 
contributions? If, as stated by many government officials during the seminars, the current planning rules are ineffective, can these policies be improved or modified to make them more effective? If so, is this a question of reducing regulation and promoting a more discretional system? Are there any other tools that can be implemented that are not currently being considered? For example, what can Latin America learn from unplanned informality?

\section{Affordable housing}

Current strategies of peripheral mass housing, which are perhaps economically viable and aim at boosting the construction sector, must be re-evaluated in terms of their social and environmental costs. What is the environmental footprint of such large schemes? What is the cost of social segregation of an already marginalized group of the population? Other areas that need revision include financial mechanisms for development and maintenance of building stock, and the impact of subsidies on the housing market, including default mechanisms. How do exfavela communities deal with living in a capitalist system, with mortgage payments and debt? Are they equipped to understand the consequences of default?

\section{Social cohesion and community building}

It was clear that the de-politicization of planning was necessary and that community participation was a good base to start such process. But lack of clear methodology for community engagement appeared to be obstructing progress. Further research is needed on current methods applied for participatory planning at the neighbourhood level as well as the level of housing schemes and new housing blocks. How to help thousands of favela dwellers make the transition towards their new buildings and new communities? What tools can be implemented for this? How will these new community members understand their responsibility in the maintenance of their buildings and their public spaces?

\section{Citizens' rights to quality of buildings and urban space}

Government officials of participating countries acknowledged that the quality of the built environment has been overlooked. However, pressure from local communities and the civic society is mounting and governments are now directing their efforts to improving the quality of the public realm as well as that of housing schemes. The general consensus during the seminars was that improving finance and taxation mechanisms for development will provide extra funds to improve the quality of the built environment. But government officials stated that they are uncertain as to how to implement better standards. What is needed is a review of current data collected by NGO such as Cómo Vamos and Techo to evaluate how municipalities can use this data to improve urban quality. It is also important to evaluate practices from other regions in the world that have succeeded in improving design quality, and test the feasibility of their transfer to the Latin American context.

The question of equitable distribution of urban benefits was much discussed during all the seminars. The big challenge for the region is how to achieve high-quality urban environments that are accessible to all sectors of the population at minimum environmental cost, while undergoing a process of rapid development and growth. This is a complex task that demands interdisciplinary action. The development of the proposed research agenda intends to aid policymakers and practitioners to achieve this goal. 


\section{Acknowledgments}

The authors are grateful to Fundação de Amparo à Pesquisa do Estado de São Paulo (Foundation for Research Support of the State of São Paulo, Fapesp); Royal Institution of Chartered Surveyors (RICS); Reading Real Estate Foundation (RREF); Henley Business School, University of Reading; and the Universities of São Paulo and Pontificia Universidad Javeriana for the funding received to carry out this work. Equally we are grateful to all participants that contributed with their knowledge and good spirit in engaging in all workshops and round table discussions. A final thanks to UN- Habitat for the opportunity to disseminate our work during the World Urban Forum 7 in Medellin in 2014.

\section{Bibliography}

Abiko, A., \& Coutanceau, P. A. (2013). Slum upgrading as a contribution to a more sustainable city. Proceedings of the Sustainable Building Conference, SB13-Realising sustainability in the Tropics. Retrieved from http://www.irbnet.de/daten/ iconda/CIB_DC26311.pdf

Abramo, P. (2008). El mercado del suelo informal en favelas y la movilidad residencial de los pobres en las grandes metrópolis: un objeto de estudio para América Latina. Territorios 18-19, 55-73.

Bäbr, J., \& Borsdorf, A. (2005). La ciudad latinoamericana. La construcción de un modelo. Vigencias y perspectivas. ur[b]es, 2(2), 207-221.

Bernardi, L., Barreix, A., Marenzi, A., \& Profeta, P. (2007). Tax Systems and Tax Reforms in Latin America. Retrieved from http://www. cepal.org/ilpes/noticias/paginas/4/29744/alberto_barreix_tax_systems_and_tax_reform_ in_la07_cap1a5.pdf
Betancour, J. (2007). Approaches to the Regularisation of Informal Settlements: The Case of Primed in Medellin, Colombia. Global Urban Development, 3(1), 1-15.

Biderman, C. (2008). São Paulo's Urban Transport Infrastructure. Retrieved from http://downloads. Isecities.net/0_downloads/archive/_SA/13_NewsPaper_Essay_Biderman.pdf

Bird, R. (2003). Taxation in Latin America: reflections on sustainability and the balance between equity and efficiency. Retrieved from http://www1. worldbank.org/publicsector/learningprogram/ PracticalIssues/papers/introduction $\% 20$ to $\% 20$ tax\%20policy/ITP0306.pdf

Boldarini Arquitetura e Urbanismo (ed.). (2008). Urbanização de favelas. A experiência de São Paulo. São Paulo: Prefeitura de São Paulo, Habitação.

Brain, I., \& Sabatini, F. (2006). Los precios del suelo en alza carcomen el subsidio habitacional, contribuyendo al deterioro en la calidad y localización de la vivienda social. ProUrbana, 2-13.

Bulkeley, H., \& Betsill, M. (2005). Rethinking sustainable cities: multilevel governance and the "urban" politics of climate change. Environmental Politics, 14(1), 42-63.

Burgess, R., Carmona, M., \& Kolstee, T. (1997). The Challenge of Sustainable Cities: Neoliberalism and Urban Strategies in Developing Countries. London: Zed Books.

Chiape de Villa, M. L. (1999). La politica de vivienda de interés social en Colombia en los noventa. Santiago de Chile: Cepal.

Chomsky, N. (2010). Hopes and Prospects. London: Hamish Hamilton. 
Clift, J. (2003). Hearing the Dogs Bark. Jeremy Clift Interviews Development Guru Hernando de Soto. Retrieved from http://www.imf.org/external/pubs/ft/fandd/2003/12/pdf/people.pdf

Cuervo, N., \& Jaramillo, S. (2009). Dos décadas de política de vivienda en Bogotá apostando por el mercado. In Universidad de los Andes (series editor), Documentos CEDE 31. Bogota: Universidad de los Andes.

De Duren, N. (2006). Planning à la carte: The Location Patterns of Gated Communities around Buenos Aires in a Decentralised Planning Context. International Journal of Urban and Regional Research, 30(2), 308-327.

De França, M. \& Abiko, A. (2013). Minha casa minha vida: uma avaliação preliminar. Available at http://lares.org.br/Anais2013/artigos/895-1041-1-SP.pdf

De la Torre, A., Fajnzylber, P., \& Nash, J. (2009). Low Carbon, High Growth: Latin American Responses to Climate Change. An Overview. Washington D. C.: The World Bank.

De Soto, H. (2001). The Mystery of Capital: Why Capitalism Triumphs in the West and Fails Everywhere Else. London: Black Swan.

Dovers, S. (1995). A Framework for Scaling and Framing Policy Problems in Sustainability. Ecological Economics, 12, 93-106.

Eclac. (2010). Time for Equality: Closing Gaps, Opening Trails. 33rd Session of Economic Commission for Latin America and the Caribbean. Brasilia: Author.

Eclac. (2012). Structural Change for Equality: An Integrated Approach to Development. 34th Session of Economic Commission for Latin America and the Caribbean. San Salvador: Author.
Eclac. (2014). Compacts for Equality. Towards a Sustainable Future. 35th Session of Economic Commission for Latin America and the Caribbean. Lima: Author.

Fernandes, E. (2002). The Influence of de Soto's The Mystery of Capital. Land Lines, 14(1), 4-7.

Formoso, C., Leite, F., \& Miron, L. (2011). Client Requirements Management in Social Housing: A Case Study on the Residential Leasing Program in Brazil. Journal of Construction in Developing Countries, 16(2), 47-67.

Frankema, E. H. P. (2006). The colonial roots of Latin American land inequality in a global comparative perspective: factor endowments, institutions or political economy? Retrieved from http://www. researchgate.net/publication/229051616_The_ Colonial_Roots_of_Latin_American_Land_Inequality_in_a_Global_Comparative_Perspective_Factor_endowments_Institutions_or_Political_Economy

Fukuyama, F. (2008). Falling Behind: Explaining the Development Gap between Latin America and the United States. Oxford: Oxford University Press.

Gilbert, A. (1997). On Subsidies and Home-Ownership. Colombian Housing Policy During the 1990s. Third World Planning Review 19(1), 51-69.

Gilbert, A. (2002). On the Mystery of Capital and the Myths of Hernando de Soto: What Difference Does Legal Title Make? International Development Planning Review, 24(1), 1-20.

Gilbert, A., \& Ward, P. (1984). Community Participation in Upgrading Irregular Settlements: The Community Response. World Development, 12(9), 913-922. 
Glaeser, E. (2011). The Triumph of the City: How our Greatest Invention Makes us Richer, Smarter, Greener, Healthier, and Happier. London: Macmillan.

González, I., \& Martner, R. (2012). Superando el "síndrome del casillero vacío" determinantes de la distribución del ingreso en América Latina. Revista Cepal, 108, 7-25.

Gupta, J., Van der Leeuw, K., \& De Moel, H. (2007). Climate Change. A “Glocal” Problem Requiring "Glocal” Action. Journal of Integral Environmental Sciences, 4(3), 139-148.

Harvey, D. (2012). Rebel Cities: From the Right to the City to the Urban Revolution. London: Verso.

Heras Gómez, L. (2004). Cultura política y democratización en América Latina. Ciencias Sociales, 103-104, 23-37.

Hills, J., Brewer, M., Jenkins, S., Lister, R., Lupton, R., Machin, S. et al. (2010). An Anatomy of Economic Inequality in the UK: Report of the $\mathrm{Na}$ tional Equality Panel London. London: Government Equalities Office.

International Labour Organization. (2014). Global Employment Trends 2014: The Risk of a Jobless Recovery. Retrieved from http://www.ilo. org/global/research/global-reports/global-employment-trends/2014/WCMS_233953/lang-en/index.htm

Jackson, T. (2009). Prosperity without Growth: Economics for a Finite Planet. London: Routledge.

Jaffe, A., \& Soligo, R. (2000). Energy in Cuba. Retrieved from http://bakerinstitute.org/media/ files/files/39de35aa/SoligoJaffe_EnergyCuba.pdf

Jenks, M., \& Burgess, R. (2000). Compact Cities: Sustainable Urban Forms for Developing Countries. London: Spon Press.
Kowaltowski, D., Gomes da Silva V., Pina, S., Labaki, L., Ruschel, R., \& Carvalho Moreira, D. (2006). Quality of Life and Sustainability Issues as Seen by the Population of Low-Income Housing in the Region of Campinas, Brazil. Habitat International, 30(4), 1100-1114.

Lall, S. (2013). Planning Connecting and Financing Cities Now. Priorities for City Leaders. Washington D. C.: World Bank Group.

Lankao, P. (2007). Are We Missing the Point? Particularities of Urbanization, Sustainability and Carbon Emissions in Latin American Cities. Environment and Urbaniaation, 19(1), 159-175.

Lima, J. (2006). Urban Reform and Development Regulation: The Case of Belem, Brazil. In R. Zetter, \& G. Butina Watson (eds.), Designing Sustainable Cities in the Developing World (pp. 159-175). Hampshire: Ashgate.

Montaner, C. (2001). Las raices torcidas de América Latina. Barcelona: Plaza \& Janés.

Murillo, F. (2001). Private-Public Partnership, the compact City, and Social Housing: Best Practice for whom? Development in Practice, 11 (23), 336-343.

Murray, C. (2013). Social Housing in Latin America: Red Road Flats of Tomorrow? Academy of Urbanism Journal, 2, 12-14.

Murray, C. (in press). Social Inequality and Real Estate in Latin America: Approaches in Argentina, Brazil, Chile and Colombia. In R. Abdulai, F. Obeng-Odoom, E. Ochieng, \& V. Maliene (eds.), Real Estate, Construction and Economic Development in Emerging Market Economies. London: Routledge.

Nicholson, R. (2013). Minha casa minha vida. Unpublished report. 
Nygaard, C. (2011). International Migration, Housing Demand and Access to Home Ownership. Urban Studies, 48(11), 2211-2229.

Onursal, B., \& Gautam, S. (1997). Vehicular Air Pollution. Experiences from Seven Latin American Urban Centres. In World Bank (series editor), Technical Paper: 373. Washington D. C.: The World Bank.

Parker, G., \& Murray, C. (2012). Beyond Tokenism? Community-Led Planning and Rational Choices. Findings from Participants in Local-Agenda Setting at the Neighbourhood Scale in England. Town Planning Review, 83(1), 1-28.

Parris, T., \& Kates, R. (2003). Characterizing and Measuring Sustainable Development. Annual Review of Environment and Resources, 28, 559-586.

Romero, H., \& Ordenes, F. (2004). Emerging Urbanization in the Southern Andes. Environmental Impacts of Urban Sprawl in Santiago de Chile on the Andean Piedmont. Mountain Research and Development, 24(3), 197-201.

Romero, H., Ihl, M., Rivera, A., Zalazar, P., \& Azocar, P. (1999). Rapid Urban Growth, LandUse Changes and Air Pollution in Santiago, Chile. Atmospheric Environment, 33(24-25), 4039-4047.

Samuelson, R. (2001). The Spirit of Capitalism. Foreign Affairs, 80(1), 205-211.

Satterthwaite, D., Huq, S., Pelling, M., Reid, H., \& Lankao, P. R. (2007). Adapting to Climate Change in Urban Areas. The Possibilities and Constrains in Low-and-Middle-Income $\mathrm{Na}$ tions. In International Institute for Environment and Development (series editor), Human Settlements Discussion Paper series: Climate Change and Cities-1. London: IIED.
Scheinshon, M., \& Cabrera, C. (2009). Social Movements and the Production of Housing in Buenos Aires. When Policies are Effective. Environment and Urbanization, 21, 109-125.

Smolka, M. O. (2012). A New Look at Value Capture in Latin America. Land Lines, 10-15. Retrieved from http://www.lincolninst.edu/ pubs/2099_A-New-Look-at-Value-Capture-inLatin-America

Smolka, M. O. (2013). Implementing Land Value Capture in Latin America. Policy Focus Report, Policies and Tools for Urban Development. Retrieved from https://www.lincolninst.edu/pubs/2244_ Implementing-Value-Capture-in-Latin-America

Stiglitz, J. (2003). Globalization and its Discontents. London: Penguin Books.

Swinton, S., Escobar, G., \& Reardon, T. (2003). Poverty and Environment in Latin America: Concepts, Evidence and Policy Implications. World Development 31(11), 1865-1872.

Thibert, J., \& Osorio, G. A. (2014). Urban Segregation and Metropolitics in Latin America: The Case of Bogota, Colombia. International Journal of Urban and Regional Research, 38(4), 1319-1343.

Thuillier, G. (2005). Gated Communities in the Metropolitan Area of Buenos Aires, Argentina: A Challenge for Town Planning. Housing Studies, 20(2), 255-2571.

Tironi, M. (2009). The Lost Community? Public Housing and Social Capital in Santiago de Chile, 1985-2001. International Journal of Urban and Regional Research, 33(4), 974-996.

UN-Habitat. (2011). Affordable Land and Housing in Latin America and the Caribbean. Nairobi: UNON. 
Van Gelder, J. L. (2009). Legal Tenure Security, Perceived Tenure and Housing Improvement in Buenos Aires: An Attempt towards Integration. International Journal of Urban and Regional Research, 33(1), 126-146.

Vercoe, R., \& Brinkmann, R. (2012). A Tale of Two Sustainabilities: Comparing Sustainability in the Global North and South to Uncover Meaning for Education. Journal of
Sustainability Education. Retrieved from http://www.jsedimensions.org/wordpress/ content/a-tale-of-two-sustainabilities-comparing-sustainability-in-the-global-northand-south-to-uncover-meaning-for-educators_2012_03/

Wilkinson, R., \& Pickett, K. (2009). The Spirit Level: Why Equality is Better for Everyone. London: Penguin Books. 


\section{Appendix}

Appendix 1.

Participating organizations

\begin{tabular}{|c|c|c|c|}
\hline Sector & Organisation & Country & \\
\hline Academic & University of Belgrano & Argentina & $\begin{array}{l}\text { Academics from the School of Architecture } \\
\text { and RE programmes. }\end{array}$ \\
\hline Academic & University of Buenos Aires & Argentina & Academics from the School of Architecture \\
\hline Academic & University of Sao Paulo & Brazil & $\begin{array}{l}\text { Academics from the School of Architecture and } \\
\text { students from the master in Real Estate. }\end{array}$ \\
\hline Academic & University of Panama & Panama & Academics from the School of Architecture \\
\hline Academic & Pontificia Javeriana University & Colombia & $\begin{array}{l}\text { Academics from the School of Architecture and } \\
\text { students from the master in urbanism }\end{array}$ \\
\hline Academic & $\begin{array}{l}\text { INJAVIU (Housing and urbanism } \\
\text { research Institute) }\end{array}$ & Colombia & Director of Research \\
\hline Charity & Architecture for Humanity & Colombia & Latin American Director \\
\hline Charity & Fundacion Mario Santo Domingo & Colombia & Director \\
\hline Corporate Organisation & CBRE Investors & UK & Chairman of Investment Committee \\
\hline Corporate Organisation & Brookfield Finance & Brazil & Director Investment and other members \\
\hline Government & Ministry of Cities & Brazil & $\begin{array}{l}\text { Director of Housing and other officials } \\
\text { and government consultants. }\end{array}$ \\
\hline Government & Findeter & Colombia & Director of Sustainable Cities \\
\hline Government & Municipality of Caracas & Venezuela & Director of Planning \\
\hline Government & Empresa de Acueducto de Bogota & Colombia & Engineer \\
\hline Government & National Bank of Colombia & Colombia & Economist and Housing Index specialist \\
\hline Government & Metro de Panama & Panama & Director \\
\hline Industry Organisation & Camacol & Colombia & President \\
\hline Industry Organisation & $\begin{array}{l}\text { CCCS (Colombian Council of } \\
\text { Sustainable Construction) }\end{array}$ & Colombia & Director \\
\hline Industry Organisation & $\begin{array}{l}\text { CBCS (Brazilian Council of Sustainable } \\
\text { Construction) }\end{array}$ & Brazil & Chairman \\
\hline Industry Organisation & Academy of Urbanism & UK & Director \\
\hline Industry Organisation & RICS & UK & President \\
\hline Industry Organisation & RICS & Brazil & Country Manager \\
\hline Industry Organisation & ABECIP & Brazil & Past-Director and other members \\
\hline International Organisation & UN Human Settlements Programme & Colombia & Director Medellin Asud Planning Programme \\
\hline NGO & Como Vamos & Colombia & Director \\
\hline Professional & Mario Noriega y Asociados & Colombia & Founder \\
\hline Professional & Cullinan Studio & UK & Senior Partner \\
\hline Professional & Borelli & Argentina & Developer \\
\hline
\end{tabular}

